\title{
A global view of Staphylococcus aureus whole genome expression upon internalization in human epithelial cells
} Christian Garzoni ${ }^{1}$, Patrice Francois*1, Antoine Huyghe ${ }^{1}$, Sabine Couzinet ${ }^{1}$, Caroline Tapparel ${ }^{1}$, Yvan Charbonnier ${ }^{1}$, Adriana Renzoni ${ }^{1}$, Sacha Lucchini ${ }^{2}$, Daniel P Lew ${ }^{1}$, Pierre Vaudaux ${ }^{1}$, William L Kelley ${ }^{1}$ and Jacques Schrenzel ${ }^{1}$

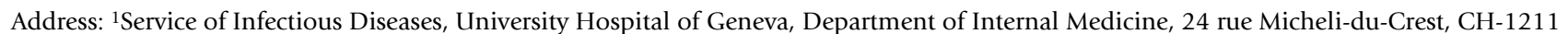
Geneva 14, Switzerland and 2Molecular Microbiology Group, Institute of Food Research, Norwich Research Park, Colney, Norwich, NR4 7UA, UK

Email: Christian Garzoni - christian.garzoni@hcuge.ch; Patrice Francois* - patrice.francois@genomic.ch; Antoine Huyghe - antoine.huyghe@genomic.ch; Sabine Couzinet - scouzinet@hotmail.com; Caroline Tapparel - caroline.tapparel@hcuge.ch; Yvan Charbonnier - yvan.charbonnier@genomic.ch; Adriana Renzoni - Adriana.renzoni@hcuge.ch; Sacha Lucchini - sacha.lucchini@bbsrc.ac.uk; Daniel P Lew - Daniel.lew@hcuge.ch; Pierre Vaudaux - Pierre.vaudaux@hcuge.ch; William L Kelley - William.kelley@hcuge.ch; Jacques Schrenzel - Jacques.schrenzel@genomic.ch

* Corresponding author

Published: 14 June 2007

BMC Genomics 2007, 8:17| doi:|0.||86/|47|-2|64-8-17|
Received: 25 September 2006

Accepted: 14 June 2007

This article is available from: http://www.biomedcentral.com/I47I-2164/8/17I

(c) 2007 Garzoni et al; licensee BioMed Central Ltd.

This is an Open Access article distributed under the terms of the Creative Commons Attribution License (http://creativecommons.org/licenses/by/2.0), which permits unrestricted use, distribution, and reproduction in any medium, provided the original work is properly cited.

\begin{abstract}
Background: Staphylococcus aureus, a leading cause of chronic or acute infections, is traditionally considered an extracellular pathogen despite repeated reports of $S$. aureus internalization by a variety of non-myeloid cells in vitro. This property potentially contributes to bacterial persistence, protection from antibiotics and evasion of immune defenses. Mechanisms contributing to internalization have been partly elucidated, but bacterial processes triggered intracellularly are largely unknown.

Results: We have developed an in vitro model using human lung epithelial cells that shows intracellular bacterial persistence for up to 2 weeks. Using an original approach we successfully collected and amplified low amounts of bacterial RNA recovered from infected eukaryotic cells. Transcriptomic analysis using an oligoarray covering the whole $S$. aureus genome was performed at two post-internalization times and compared to gene expression of non-internalized bacteria. No signs of cellular death were observed after prolonged internalization of Staphylococcusaureus 6850 in epithelial cells. Following internalization, extensive alterations of bacterial gene expression were observed. Whereas major metabolic pathways including cell division, nutrient transport and regulatory processes were drastically down-regulated, numerous genes involved in iron scavenging and virulence were up-regulated. This initial adaptation was followed by a transcriptional increase in several metabolic functions. However, expression of several toxin genes known to affect host cell integrity appeared strictly limited.
\end{abstract}

Conclusion: These molecular insights correlated with phenotypic observations and demonstrated that $S$. aureus modulates gene expression at early times post infection to promote survival. Staphylococcusaureus appears adapted to intracellular survival in non-phagocytic cells. 


\section{Background}

Staphylococcus aureus is a versatile pathogenic bacterium capable of rapidly developing or acquiring multiple antibiotic resistances, and is now recognized as a worldwide health problem [1]. S. aureus is responsible for a wide spectrum of human and animal diseases, ranging from benign skin infections to severe diseases, such as arthritis, osteomyelitis, endocarditis or fatal sepsis [2]. Acute infections are related to the organisms' capacity to secrete a plethora of exotoxins [3,4] and catabolic enzymes [2,5], as documented previously in different experimental models of acute infections [6-8]. S. aureus is also responsible for chronic diseases such as osteomyelitis [9], rhinosinusitis [10], or otitis [11]. These infections are difficult to eradicate and often relapse even after prolonged and adapted antibiotic therapy $[12,13]$, suggesting that $S$. aureus has developed specific strategies for intracellular persistence. In addition, anti-infective agents commonly used for the treatment of $S$. aureus infections could enhance selection of invasive intracellular strains [14].

In contrast to other persistent human pathogens, $S$. aureus is not traditionally considered as an intracellular pathogen [15]. Nevertheless, substantial evidence strongly supports that $S$. aureus can be internalized and survive in a variety of non-professional phagocytic cells in vitro $[2,16$ $18]$ and in vivo $[19,20]$. The endocytic uptake of $S$. aureus by non-myeloid cells involves active cellular processes that depend upon F-actin polymerization and is similar in many respects to that observed in professional phagocytes [17]. Whereas entero-invasive pathogens utilize secretion systems to actively induce their own uptake by the host cell, internalization of $S$. aureus by non-professional phagocytes shows similar efficiency in vitro with live or killed bacteria $[17,21]$. The mechanism relies on an interaction between fibronectin binding protein and host-cell $\alpha 5 \beta 1$ integrins $[17,22,23]$. The role of other bacterial surface proteins like clumping-factor A or host cell Src kinase also appears important in the mediation of $S$. aureus uptake and intracellular persistence $[18,24]$. After internalization, the behavior of the bacterium varies according to cell-line or bacterial strain. For example, some authors reported active intracellular bacterial replication within vacuoles [25] or rapid bacterial escape from vacuole and induction of cellular apoptosis [26-28], while others described persistence for several days before induction of escape processes [29]. The production of $\alpha$-toxin appears correlated with the induction of apoptosis [27,30,31]. Regulation of $\alpha$-toxin expression is complex and involves multiple regulators that include agr, sarA homologues, or svrA [32-35].

Molecular details that govern $S$. aureus extended persistence are largely unknown. Metabolic alterations leading to small colony variant (SCV) microorganisms are one possibility that has been described [36-38]. Such S. aureus variants were recently shown to efficiently invade endothelial cells in vitro and display a markedly higher content in fibronectin-binding proteins than the parental strain [39]. SCVs display a major alteration in their ability to produce or export exotoxins [36] and reveal extensive changes in their global regulatory network [40]. Overall this persistent behavior, possibly related to alteration of regulatory networks, appears compatible with the property of $S$. aureus to generate relapsing infections even years after a first episode was apparently cured [36,41].

Several studies have examined details of cellular responses after $S$. aureus internalization in either phagocytic or nonphagocytic cells $[42,43]$. However, little is known about bacterial gene expression upon cellular internalization. Recent efforts in high throughput sequencing have contributed to the elucidation of numerous bacterial genomes. To date, eight fully annotated $S$. aureus genomes are publicly available [44-49] allowing the design of DNA microarrays to probe the bacterial transcriptome [50-54], or to catalogue and type variation among clinical isolates $[53,55,56]$.

In this study, we describe an in vitro model where $S$. aureus is able to persist for up to two weeks in the absence of either cellular death or emergence of small colony variants. S. aureus gene expression changes between adherent bacteria and those arising $2 \mathrm{~h}$ and $6 \mathrm{~h}$ after cellular internalization were compared using a custom-designed and validated S. aureus oligoarray [53]. Profound shut-down of gene expression was observed shortly after internalization for bacterial metabolic functions and transport. This period was followed by resumption of transcriptional activity for metabolic and energy production functions correlating with moderate bacterial multiplication. These findings suggest that $S$. aureus extensively reprograms its transcriptome to adjust to the intracellular environment. Detailed study of these changes may help understanding the molecular mechanisms governing establishment and maintenance of persistent $S$. aureus infections and potentially helpful for the design of new antibacterial drugs.

\section{Results \\ Infection model and bacterial RNA isolation}

We developed a model system that displayed protective survival of $S$. aureus 6850 within human lung epithelial cells A549. Control experiments were performed to examine infection parameters and determine the saturation of internalization. Figure 1A shows bacterial internalization as a function of the multiplicity of infection (m.o.i). The profile describes a linear dose-response until saturation for m.o.i higher than $286 \mathrm{~S}$. aureus per cell. We next examined the intracellular survival of strain 6850 as a function of time using the lysostaphin/gentamicin protection 

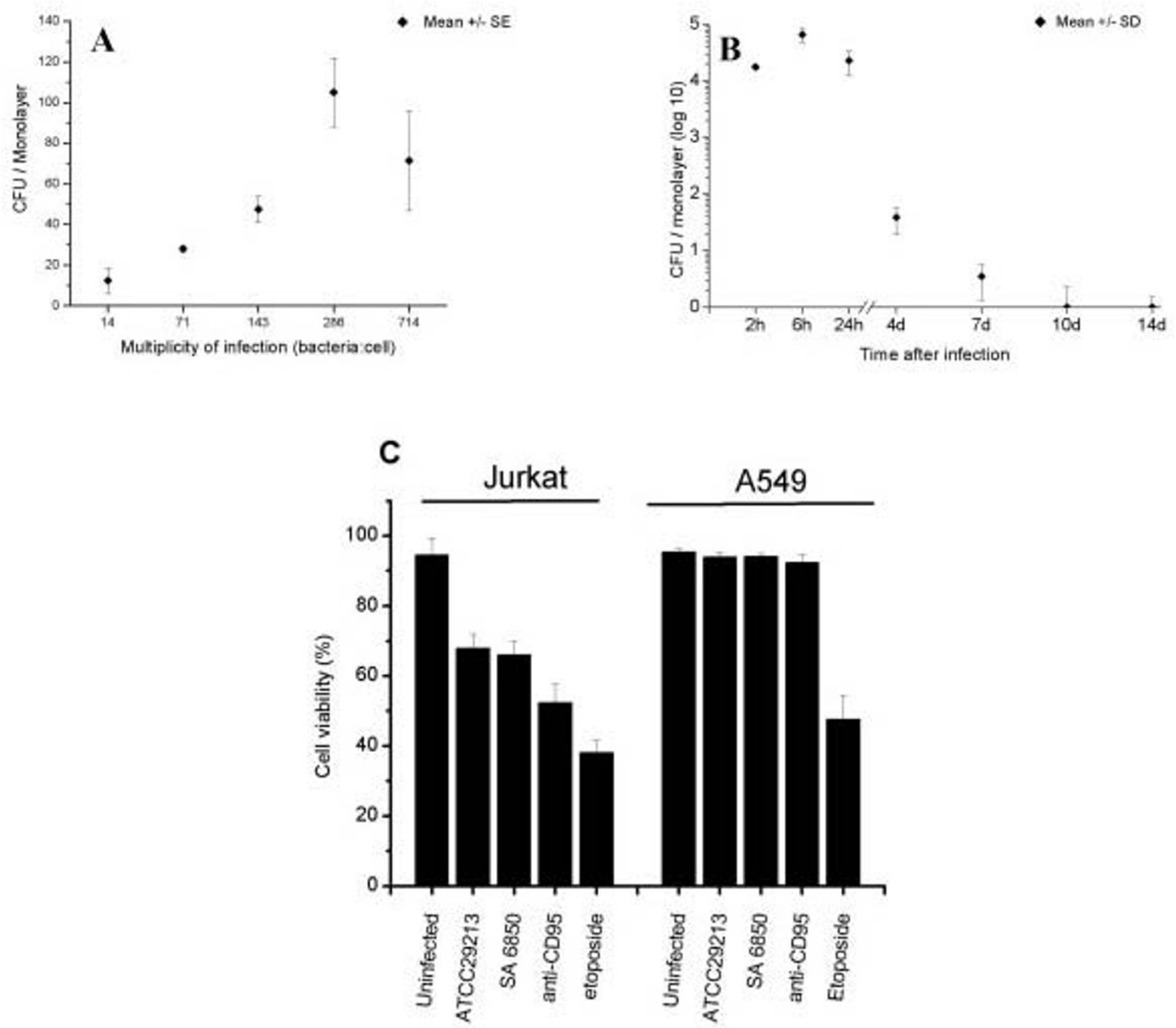

Figure I

Internalization of S. aureus 6850 by A549 cells. A. Dose-response of internalization assay performed by adding increasing number of bacteria to constant number of cells. The internalization assay was performed as described in the experimental section. After $2 \mathrm{~h}$, cells were detached with trypsin lyzed with dilute Triton X-100, and then internalized bacteria were assessed by count of colony forming units (cfu). B. Intracellular survival assay of S. aureus over a two-week interval. Note that at times after 6 hours, viable bacterial counts decreased, though viable bacteria were recovered from monolayers even 2 weeks after internalization. All values are mean \pm standard deviation (SD) of at least three independent experiments. C. Viability tests were performed after 24 hours of internalization using bacterial m.o.i. of I00:I, or the presence of anti-CD95 (I $\mu \mathrm{g} / \mathrm{ml})$ or etoposide ( $100 \mu \mathrm{M}$ final concentration) as pro-apoptotic controls.

assay, as shown Figure $1 \mathrm{~B}$. We observed substantial intracellular survival during the first 24 hour post-internalization. Notably, we observed a 3-fold increase in viable bacteria recovered at 6 hours post internalization compared with 2 hours indicating most probably that bacterial replication, or completion of cell division, had occurred. Viable bacterial counts diminished slightly in the 6-24 h interval. A 3 log decrease in recovered bacteria was observed in the interval from 1-4 days post-infection indicating substantial infection clearance. Nevertheless, viable bacteria could be recovered in this model system up to 2 weeks post infection. Strain 6850 produces strong $\alpha$ - 

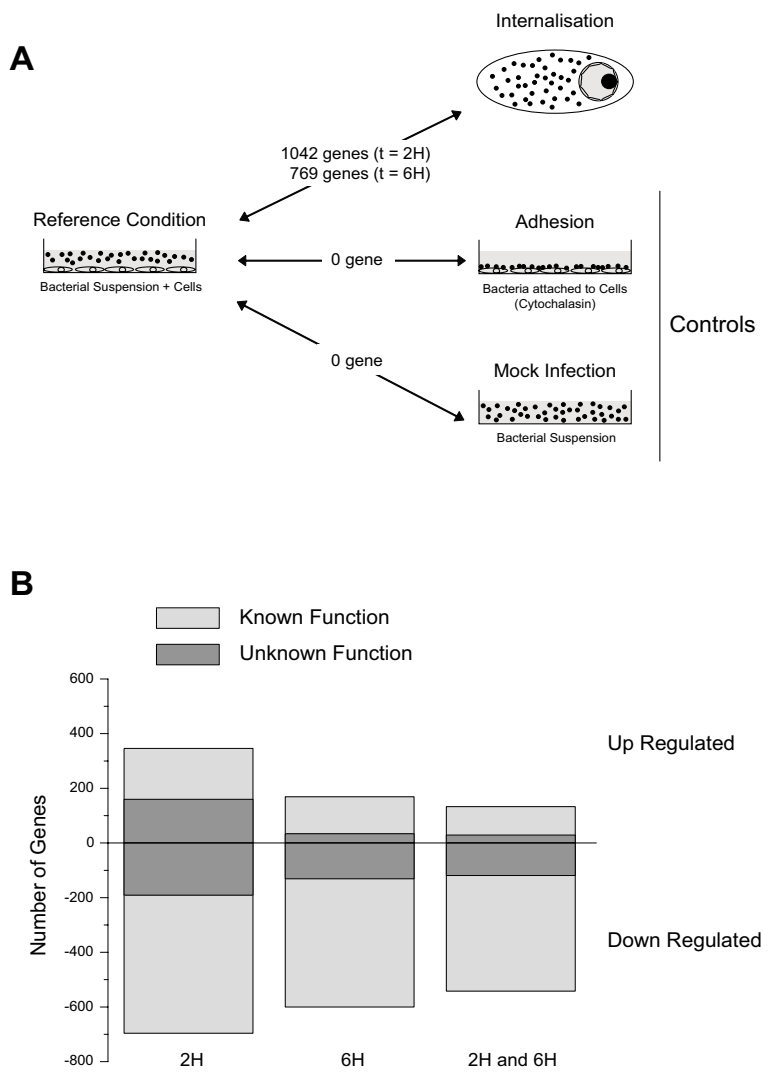

\section{Figure 2}

Schematic representation of conditions subjected to microarray analysis and number of differentially expressed genes. A. Similar expression profiles were observed for the comparisons between the reference condition and the control conditions consisting in i) mock infection (bacteria in cell culture medium) or ii) adherent bacteria (in the presence of cytochalasin D I $\mu \mathrm{g} / \mathrm{ml}$ ). On the opposite, an important number of genes were found differentially regulated between reference condition and internalized bacteria after 2 or $6 \mathrm{~h}$ of intracellular survival. See material and methods section for details. B. Numbers of genes found differentially regulated are indicated for each condition. The proportion of non-characterized genes annotated as genes with "unknown function" appears dark grey.

toxin amounts as revealed on blood agar plates as well as in strains recovered from the intracellular survival assay (data not shown). We observed no emergence of SCV at any time point in the assay. We conclude that the model reflects both a window of bacterial survival and replication as well as persistent infection and we focused in early time-points $(2,6$ hours $)$ for subsequent detailed study. Microscopic observations with trypan blue revealed no significant cytotoxicity as well as the absence of any cellular morphologic alteration during the first 14 days of co- incubation (Figure 1B). Subsequent viability assays were performed at a sub-saturating m.o.i. of 100:1 using strains 6850 or ATCC29213, previously described as cytotoxic in other cell lines $[27,30,31]$. Control Jurkat T cells revealed altered cellular viability in the presence of any of the two bacterial strains or by contact with pro-apoptotic compounds (Figure 1C). In contrast, a total absence of cellular toxicity was observed in A549 cells in the presence of either 6850 or ATCC strains. Similarly to previously published observation [57], anti-CD95 failed also to affect A549 viability whereas etoposide showed a significant impact on A549 viability (Figure 1C).

Purification of bacterial RNA from intracellular bacteria proved difficult due to significant excess of eukaryotic material. After protocol optimizations, the extraction and amplification procedures showed appreciable reproducibility (additional file 1) with Pearson correlation value of 0.9-0.93, an important parameter in microarray experiments $[58,59]$. Nevertheless, bacterial RNA preparations contained detectable contaminating RNA traces from host-cell. Absence of detectable cross-hybridization on the microarray with cellular RNA demonstrates the high specificity of the microarray for bacterial messengers resulting from the design strategy (data not shown).

\section{Analysis of gene expression changes in extracellular and adherent bacteria}

We first performed several microarray experiments to evaluate the impact of cell culture medium, presence of cells, presence of cytochalasin $\mathrm{D}$, and bacterial attachment to cells, on the bacterial transcriptome expression. The experimental design and pairwise comparisons performed are depicted in Figure 2A. The following conditions were tested: i) bacteria propagated in invasive medium alone, ii) non-adherent bacteria cultivated in the presence of cells, iii) non-adherent bacteria recovered from infections in the presence of cytochalasin D, and iv) cell-adherent bacteria in the presence of cytochalasin D. No significant changes in gene regulation were recorded from all possible pair-wise comparisons. We conclude from this analysis that exposure of bacteria to our experimental parameters prior to cellular internalization does not result in detectable alteration of bacterial transcriptome. We then compared expression values obtained at time 0 in the culture medium against those obtained after 2 or 6 hours of internalization.

\section{Analysis of intracellular bacterial gene expression changes} Previous studies performed in our laboratory indicated that bacterial uptake by both A549 and MRC5 lung epithelial cells is a rapid process ( $<30$ minutes) [17]. From this result, as well as those presented in Figure 1B, we reasoned that 2 and 6 hour time points would reveal new information about bacterial transcriptomic program 
required for early essential adaptation to the intracellular environment. We therefore evaluated the transcriptome of S. aureus after 2 and $6 \mathrm{~h}$ post-internalization.

Comparison of gene expression between control (time 0) and $2 \mathrm{~h}$ or $6 \mathrm{~h}$ post-infection conditions revealed extensive modifications in bacterial gene regulation. The complete raw data set as imported from the array scanner as well as the $2 \mathrm{~h}, 6 \mathrm{~h}$, and functional group cluster is available online [60].

Statistically significant changes in gene expression were found for 1042 and 766 genes after $2 \mathrm{~h}$ or $6 \mathrm{~h}$ of infection, respectively (including 338 and 165 hypothetical proteins). After $2 \mathrm{~h}$ of infection, 346 genes were up-regulated whereas 696 were down-regulated, while 169 genes were found up-regulated and 600 genes down-regulated $6 \mathrm{~h}$ post-infection (Figure 2B). The numbers of genes showing differential expression levels only for one of the two timepoints were 89 and 362 for 2 or 6 h, respectively. Since all tested control conditions did not result in significant changes in gene expression, we conclude that these massive alterations in transcription profiles are triggered upon bacterial internalization.

\section{Clustering and functional group assignment}

Differentially expressed genes were clustered by functional group categories according to the COG classification [61] (additional file 2). An additional category consisting in documented virulence factors was added (Table 1 and Figure 3), according to established criteria [62]. Overall, the general trend revealed a substantial down-regulation of genes involved in metabolic functions (additional file 3). For example, among the 55 ORFs encoding for ribosomal proteins, $>40$ were found downregulated at $2 \mathrm{~h}$, or $6 \mathrm{~h}$. This reduction concerned also the totality of the atp operon (atpA to atpH) responsible for ATP synthesis and genes involved in nucleotide and amino acid metabolism. Note however that the majority of these genes were up-regulated between 2 and 6 hours. Similar responses were also observed for numerous genes involved in sugar metabolism and energy production. A more balanced picture was observed among signal transduction and transcription regulators (additional file 3 ). Changes in gene expression of hypothetical reading frames were observed to be equally distributed between down- and up-regulated genes. Among genes that were up-regulated, we noted a significant number of targets involved in iron metabolism and other inorganic ions (additional file 3) contributing to oxidative stress protection. Among the most significantly up-regulated genes, we observed defense genes, such as sodA, ahp and also transcription regulators of virulence factors (Table 1), RNAIII, sarS (also named sarH1) and svrA (SA0323 or SAV0334 according to the annotation of S.aureus N315 and Mu50, respectively) which are known to modulate the expression of the agr locus $[35,63]$. Another category showing important changes in gene expression was transporters (addi-

Table I: Genes differentially expressed involved in virulence

\begin{tabular}{|c|c|c|c|c|c|}
\hline & Common & Organism & $2 \mathrm{~h}$ fold change & $6 \mathrm{~h}$ Fold change & Protein name \\
\hline SA2423 & $C l f B$ & N3I 5 & 0.17 & 0.19 & Clumping factor \\
\hline SA229I & fnbA & N315 & 3.23 & & fibronectin binding proteins \\
\hline SA2290 & $f n b B$ & N3I5 & & 3.83 & fibronectin binding proteins \\
\hline MWI940 & $h l b$ & MW2 & 3.08 & & $\beta$-hemolysin \\
\hline SAS065 & hld & N315 & 3.05 & & $\delta$-hemolysin \\
\hline SA2209 & $h \lg B$ & N3I5 & & 3.12 & $\gamma$-hemolysin \\
\hline SA246I & $i c a B$ & N3I 5 & 3.75 & & Intercellular adhesion proteins \\
\hline SAI 638 & lukE & N315 & 3.06 & & leukotoxin LukE \\
\hline SAI 812 & $S A / 8 / 2$ & N315 & 0.14 & 0.22 & synergohymenotropic toxin precursor $S$. intermedius \\
\hline SA052I & sdrE & N3I 5 & 0.20 & 0.29 & Ser-Asp rich proteins \\
\hline SAI8I7 & $\sec 3$ & N3I5 & 3.41 & & enterotoxin type $\mathrm{C} 3$ \\
\hline MW0759 & $\sec 4$ & MW2 & 3.60 & 4.76 & enterotoxin $C$ precursor protein \\
\hline SAI 642 & seg & N315 & 4.90 & 3.70 & extracellular enterotoxin type $\mathrm{G}$ precursor \\
\hline SAI 816 & sel & N315 & 3.46 & 3.09 & extracellular enterotoxin $L$ \\
\hline SAI 648 & seo & N315 & 3.94 & 6.33 & enterotoxin $\mathrm{SeO}$ \\
\hline SAI009 & setl & N315 & 3.73 & & exotoxin I \\
\hline SA0389 & set $/ 3$ & N3I5 & 3.52 & 3.45 & exotoxin 13 \\
\hline SA0390 & set $/ 4$ & N3I 5 & 3.77 & 3.73 & exotoxin 14 \\
\hline MW0394 & set26 & MW2 & & 4.95 & exotoxin homolog [Genomic island nu Sa alpha2] \\
\hline SAIOII & set3 & N3I 5 & 5.00 & 4.69 & exotoxin 3 \\
\hline SAOI 07 & spa & N3I5 & 0.15 & 0.10 & Protein A \\
\hline SA090I & sspA & N3I5 & 0.14 & 0.11 & V8 protease \\
\hline SA0899 & $\operatorname{ssp} C$ & N3I5 & 3.22 & & Staphopain \\
\hline SAI 819 & tst & N315 & 3.80 & 4.10 & Toxic shock syndrome toxin-I \\
\hline SAI 645 & yentl & N3I5 & & 3.18 & enterotoxin YentI \\
\hline
\end{tabular}




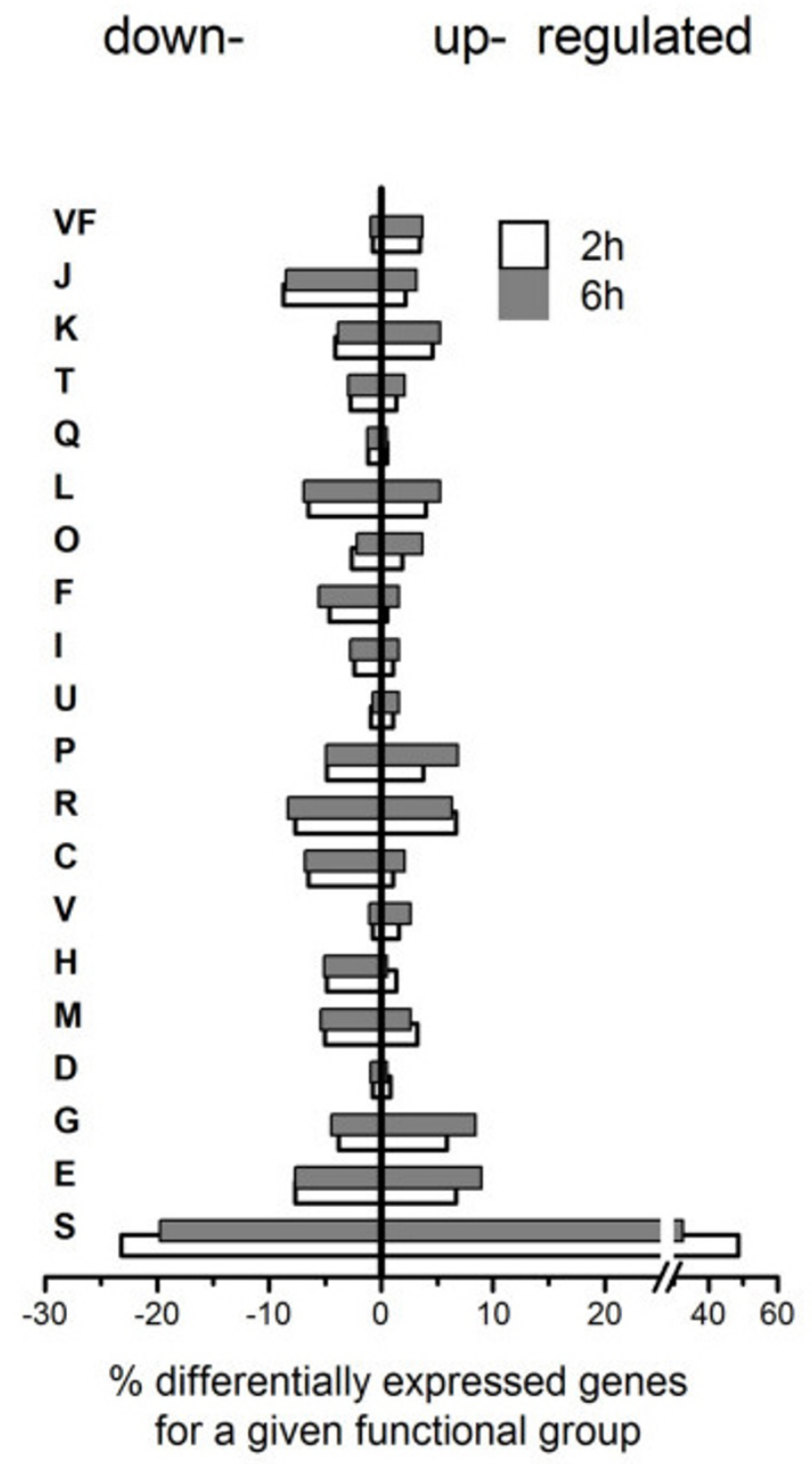

Figure 3

Changes in gene expression $2 \mathrm{~h}$ and $6 \mathrm{~h}$ after internalization shown by functional categories. Percent changes at $2 \mathrm{~h}$ (white) and $6 \mathrm{~h}$ (grey) was calculated by dividing the number of significantly changed genes by total genes at the given time point. Genes were assigned functional groups using annotated public database and metabolic pathways databases (COG). Categories are: E: Amino acid transport and metabolism, G: Carbohydrate transport and metabolism, D: Cell cycle control, cell division, chromosome partitioning, M: Cell wall/membrane/envelope biogenesis, $\mathrm{H}$ : Coenzyme transport and metabolism, V: Defense mechanisms, C: Energy production and conversion, R: General function prediction only, P: Inorganic ion transport and metabolism, U: Intracellular trafficking, secretion, and vesicular transport I: Lipid transport and metabolism, F: Nucleotide transport and metabolism, O: Posttranslational modification, protein turnover, chaperones, L: Replication, recombination and repair, Q: Secondary metabolites biosynthesis, transport and catabolism, T: Signal transduction mechanisms, K: Transcription, J: Translation, ribosomal structure and biogenesis, and VF for virulence factor.

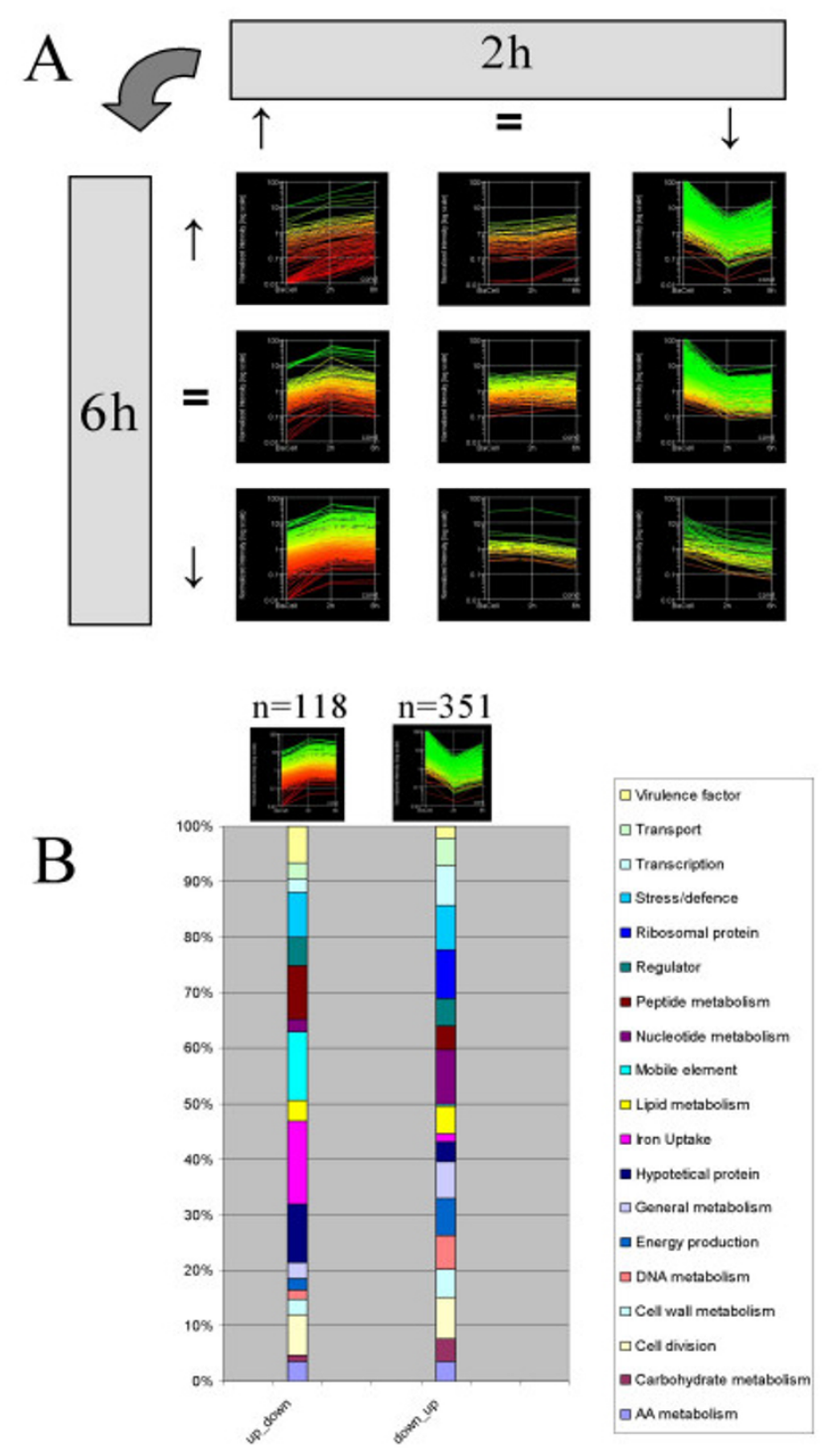

Figure 4

Global pattern of expression. Patterns of gene expression changes are shown for each of nine possible categories. The most abundant categories (B) were analyzed in depth after grouping by gene function. Numbers of genes in these two categories are also shown. 




Figure 5

Quantitative PCR validation of microarray data. Dynamic of gene expression changes is shown as fold change by real-time PCR (black bars), or by microarray determination (white bars), at $2 \mathrm{~h}(\mathrm{~A})$ or $6 \mathrm{~h}(\mathrm{~B})$ post-infection. Data are mean \pm SD of triplicate measurements from 2 independent experiments.

tional file 3). More than 40 genes were found significantly differentially regulated including transporters of iron, sugars, nucleotides and amino-acids. Importantly, expression of toxic virulence factors and $\alpha$-hemolysin were found either down-regulated, or unchanged, compared to the control conditions (Table 1). Finally, the number of genes involved in biosynthesis or degradation of bacterial envelopes showed contrasted levels of expression after internalization as compared to extracellular control bacteria (see Materials and Methods). Whereas cell-wall metabolism enzymes (the autolysin lytM, and several amidases lytA, sgtA and SA1759) showed drastic up-regulation, transpeptidase, acid techoic synthesis genes, the mur operon and several cap genes showed massive down-regulation after internalization (additional file 3).

Based on the time-points studied, two major regulation profiles were found composed of genes showing: i) large down-regulation after $2 \mathrm{~h}$, then a slight increase at $6 \mathrm{~h}$, and ii) up-regulation at $2 \mathrm{~h}$ then only marginal change at $6 \mathrm{~h}$. These two categories are presented in Figure 4A in the upper-right and lower-left corners, respectively. Grouping by functional category revealed that the first expression profile is mainly composed of mobile elements, transporters, regulators and iron metabolism (Fig. 4B). The other categories were mainly composed of genes involved in nutrient transport, general and nucleotide metabolism, and ribosomal proteins, but also in DNA replication and carbohydrate metabolism (Fig. 4B).
Analysis of gene expression changes in the interval $2 \mathrm{~h}-6 \mathrm{~h}$ post-infection. To examine gene expression changes occurring during its intracellular passage, we extracted a list of genes that were differentially expressed (determined by ANOVA) between times $2 \mathrm{~h}$ and $6 \mathrm{~h}$ after internalization. A striking up-regulation of gene expression was observed at $6 \mathrm{~h}$ post-infection in most functional categories, consistent with bacteria readapting their energy production, intermediary metabolism, protein synthesis, and nucleotide biosynthesis. This finding is consistent with metabolic restart necessary for the observed bacterial doublings in the 2-6 h time interval (Figure 1B).

\section{qPCR validation of array data for selected genes}

As an independent measure of differential gene expression, we examined the relative levels of 6 genes selected from different functional categories by quantitative realtime PCR showing up- or down-regulation or unchanged level of expression. As previously established in other studies, the absolute magnitudes of normalized signals reflects the broader dynamic range of the qPCR method compared to microarray measurements $[53,64]$. The results are shown in Figure 5 and are correlated in terms of up- or down-regulation with microarray determinations. Notably, the data confirms the observed down-regulation of agr expression correlated with the absence of hla transcription. Congruent changes were observed for lytM, sarS and sodA that showed up-regulation of their expression as previously recorded using microarrays (Figure 5).

\section{Discussion}

Recent efforts in the field of high-throughput sequencing contributed to the public release of numerous bacterial genomes of medical importance. This information allowed the development of microarrays able to monitor gene expression changes at the genome scale. We report here the utilization of a microarray covering the whole genome of Staphylococcus aureus to evaluate the behavior of the bacterium upon cellular internalization, a phenomenon potentially contributing to bacterial protection against host defenses, and important in the context of chronic infections. Our overall findings are in agreement with previous studies utilizing experimental cellular models of bacterial internalization, using either intracellular or facultative intracellular pathogens. If the ability of $S$. aureus to persist in different in vitro models is widely accepted, the capacity of $S$. aureus to escape from hostdefenses and persist intracellularly in vivo is still debated [15]. In this respect, the call to document "the presence of staphylococci within non-professional phagocytes at sites of infection in clinicopathological tissues" [15] has been recently demonstrated by Clément and colleagues, who identified $S$. aureus residing in human nasal epithelial cells in vivo, a probable cause of recurrent rhinosinusitis 
infection [19]. This in vivo survival capacity was further documented in the same population and shown to constitute a significant risk factor for recurrent episodes of rhinosinusitis refractory to antimicrobial and surgical therapy [65]. Similar behavior was also observed in an experimental model of mastitis [20].

In our model, the presence of cells or the attachment of bacteria to A549 cells (in the presence of cytochalasin) showed limited impact on bacterial transcriptome. This observation is in accordance with previous reports from our group showing that no active bacterial process is require for internalization [17]. With respect to bacterial pathogenesis, this observation suggests that $S$. aureus internalization is probably not rare as it requires only a minimal number of bacterial factors [22]. In contrast to other microorganisms known to invade eukaryotic cells and rapidly divert cellular compounds and energy to actively multiply [66], our study indicates that upon cellular internalization, $S$. aureus transiently shuts down most of its metabolic functions and adopts an apparent "dormant state" without extensively initiating classic starvation or stress process. These profound changes in the bacterial transcriptome affect approximately $40 \%$ of all putative ORFs identified in the genomic sequence of the bacterium and appear related to an extensive adaptation to the new environment constituted by the intracellular compartment. The majority of genes involved in energy production (citrate and ATP cycles, pyruvate metabolism, and oxidative phosphorylation) were drastically reduced after $2 \mathrm{~h}$ internalization, Consequently, $>75 \%$ of $S$. aureus ribosomal proteins showed a significant down-regulation, which constitutes a common trait with streptococcal exposition to endothelial cell [67], another Gram positive pathogen able to invade non-phagocytic cells before inducing apoptosis [68]. For these 2 pathogens, metabolic and cellular division machineries appear strongly downregulated rapidly after internalization [67]. This situation is markedly different from that observed in invasive intracellular pathogens such as Salmonella [69], Shigella $[66,70]$, or Pasteurella [71], which show up-regulation of most cellular processes upon internalization and are able to multiply actively before disseminating to other cells $[69,70]$. In our model, a significant increase in colony forming unit counts was observed between 2 and $6 \mathrm{~h}$ of intracellular persistence. This cellular multiplication parallels up-regulation of $l y t M$, as well as that of numerous amidases involved in cell-wall processing [72]. Concurrently, a slight up-regulation of cell-wall and techoic acid synthesis genes was observed between these time points, suggesting evidence of intracellular replication or completion of cell division, as observed in the context of $S$. aureus phagocytosis by neutrophils [43]. This metabolic evolution was paralleled by a massive up-regulation of numerous transporters. In our study, more than 40 transporters, involved in inorganic ions, nucleotides or peptides, or urea were found significantly up-regulated. Transporters involved in metabolic pathways contribute to the direct rerouting of cellular resources by the internalized bacterium. Illustrative examples are the up-regulation of $u h p T$ (observed at 2 and $6 \mathrm{~h}$ internalization), allowing glucose6-phosphate acquisition, as observed during internalization of other bacterial species $[66,70]$ or during in vitro [73] or intracellular exposition of $S$. aureus to acidic environments [43]. S. aureus genome contains 7 putative iron transporters [74] that are important mediators of bacterial virulence. Iron transporters are typically up-regulated in various internalized invasive pathogens $[67,74,75]$. In our study, isdF, SA0567 and particularly bitC, were drastically up-regulated in $S$. aureus, thus providing probably sufficient amounts of iron from the intracellular medium, whereas all genes composing the fhu operon, encoding ferric hydroxamate assimilation proteins were down-regulated, in accordance with their function of iron transporters under specific environmental conditions [76].

Intracellular survival can potentially expose the bacterium to cellular defense mechanisms such as oxygen radicals. In our study, the number of up-regulated genes involved in stress protection or bacterial defense revealed surprisingly low. Except for sodA and $c y s M$, whose products protect bacterial cell against oxidative stress [77], a majority of genes involved in oxidative stress response appeared down-regulated. This finding is markedly different than the behavior of Shigella [66], but consistent with previous reports about $S$. pneumoniae [67]. Note however that experiments performed in A549 cells failed to detect production of reactive oxygen species upon bacterial uptake (not shown). Internalized $S$. aureus appeared to solicit protective functions but in a different context than that requiring preservation of the cellular machinery integrity as described by Voyish in the context of resistance to neutrophil phagocytosis [43]. In non-phagocytic cells, the expression of capsule operon, Clp proteases family and chaperones, as well as their known regulators $c t s R$ and $\operatorname{sig} B$ [78], potentially conferring survival against toxic cellular metabolites was drastically down-regulated.

The expression of numerous bacterial virulence factors is modulated through complex networks of regulatory molecules including two-component systems and global regulators such as agr or sar. Multiple regulatory pathways contributed not only to the rapid adaptation of the bacteria to environmental changes but also to the regulation of toxins or cell-surface components expression during bacterial growth-phases $[79,80]$. In our system, upon contact with cell monolayers, strain 6850 was in early exponential phase of growth where agr activity is limited. Following internalization and metabolic restart, general metabolic functions appeared up-regulated in the absence of agr 
induction. In addition, internalized bacteria showed an increase in expression of sarS and svrA simultaneously to a marked down-regulation of saeRS genes, which are important compounds known to modulate agr expression $[35,63]$. In parallel to a moderately increased expression of RNAIII, a compound known to induce agr expression in vitro, this regulation pattern results in the reduced expression of hla that potentially mediates apoptosis induction in some systems $[25,27,30]$. This uncoupling between agr and RNAIII expression has been previously observed in vivo in an experimental model of endocarditis [81]. The restricted level of hla expression suggests a different regulation behavior under these experimental conditions or the action of another unknown regulator. The latter hypothesis is further supported by the results of Goerke [32], who showed that mutation in agr and sar had no consequence for hla expression in vivo. This unknown target is probably not $\operatorname{sig} B$, a regulator found drastically down-regulated upon internalization as well as the totality of related $r s b$ partners in our model. SigB has been recently suggested as a potential partner involved in the persistence of SCVs recovered from cystic fibrosis [82]. In our study, we failed to detect such SCVs as $S$. aureus recovered after 2 weeks of internalization yielded significant hemolysis when plated on blood agar. However, this observation does not rule out the emergence of SCVs in our model as this phenotype appears able to revert spontaneously [83]. These observations are directly related to the absence of cytotoxicity on A549 cells even after two weeks of infection, an observation common between our study and previous work using SCVs [84].

In contrast to the behavior of internalized SCVs, Bantel and colleagues reported 6850-evoked induction of apoptosis using Jurkat T cells [30], which is consistent with our control assays confirming that strain 6850 was able of provoking cytotoxic effects. In addition, Qazi and colleagues reported the induction of agr and bacterial escape from endosomal vesicles rapidly after internalization using S. aureus RN6390 and MAC-T [85]. On the contrary, Kahl reported that i) rifampicin-treated bacteria failed to induce apoptosis and that ii) Cowan I -a strain that failed to multiply in epithelial cells- does not show appreciable cytotoxic effects [25]. These observations are important concerning $S$. aureus pathogenicity and suggest that certain combinations of host cells and bacteria can result in different biological outcomes. Altogether, results obtained with different models strongly suggest that the internalization of $S$. aureus is a key factor in chronic infections, as intracellular survival occurs in cells showing a long lifespan such as fibroblasts or epithelial cells. $S$. aureus intracellular survival appears related to its capability to adopt a discrete behavior instead of actively duplicating. S. aureus then benefits from natural or programmed cell death to re-emerge and trigger another episode of infection, leading to chronicity.

\section{Conclusion}

Internalization of $S$. aureus in non-phagocytic cells explaining its resistance properties against cellular or humoral host defenses is an attractive hypothesis relying on its particular ability to generate chronic diseases. In our model of cellular persistence, S. aureus strain 6850 is able to reside intracellularly for prolonged period of time. Microarray experiments provide a global picture of genes possibly involved in $S$. aureus pathogenesis, and in particular, the capacity of the bacterium to diminish most of its metabolic functions, despite soliciting numerous transporters allowing maintenance of vital functions but limiting its multiplication. Limited bacterial growth and expression of regulators of virulence factors leads to a finely controlled expression of cell-active toxins insuring intracellular bacterial survival. Global bacterial responses upon internalization appears complex but in accordance with the capacity of the bacterium to reside intracellularly. Finally, the study has uncovered dozens of potential targets for anti-infective therapeutics.

\section{Methods}

Bacterial strains and cell culture

A549 cells (ATCC CCL-185, human lung adenocarcinoma) were maintained under $5 \% \mathrm{CO}_{2}$ in minimal essential medium (MEM, Gibco) supplemented with $10 \%$ heatinactivated fetal calf serum (Gibco) and $100 \mathrm{U}$ penicillin/ $\mathrm{ml}$. Two days prior to infection, $6 \times 10^{6}$ cells were seeded in $10 \mathrm{~cm}$ wells yielding weakly confluent monolayers $(2 \times$ $10^{7}$ cells/well) at the time of infection. S. aureus 6850 is derived from multifocal osteomyelitis, is fully pigmented, and maintains a stable virulence phenotype [86]. Overnight cultures in Mueller-Hinton broth (MHB, BD-Difco) were diluted with fresh media and grown to early log phase for 3 hours. Cells were washed twice in PBS, filtered ( $5 \mu \mathrm{m}$, Sartorius) to reduce aggregation and re-suspended in MEM at $1 \times 10^{9}$ cells $/ \mathrm{ml}$. Jurkat T cells (kind gift of D. Trono, Univ. of Geneva) were cultivated in RPMI (Gibco) supplemented with $10 \%$ heat-inactivated fetal calf serum (Gibco) and $100 \mathrm{U}$ penicillin/ml.

\section{Cell infection and control conditions}

Three hours before infection, A549 cells were washed once with MEM, then placed in $5.5 \mathrm{ml}$ invasion medium (IM) consisting of MEM enriched with $10 \%$ human albumin (ZLB Biopharma). Infections were initiated with a multiplicity of infection (m.o.i. 100:1 bacteria/cells) using bacteria in early logarithmic growth phase $\left(\mathrm{OD}_{600}=\right.$ 0.2 ). Cultures were incubated $30 \mathrm{~min}$ at $37^{\circ} \mathrm{C}$ in $5 \% \mathrm{CO}_{2}$ with $2 \times 10^{9}$ washed bacteria to allow adhesion and internalization. Non-adherent bacteria were collected (control bacteria) and fixed with ice cold acetone/EtOH (1:1). 
Infected monolayer cells were washed twice with MEM to remove residual non-adherent bacteria then incubated 20 $\min$ at $37^{\circ} \mathrm{C}$ in MEM supplemented with $4 \mu \mathrm{g} / \mathrm{ml}$ lysostaphin. Cells were then washed twice with MEM and placed in $20 \mathrm{ml}$ MEM containing $100 \mu \mathrm{g} / \mathrm{ml}$ gentamicin (defines time $=0$ ). At 2 and 6 hours post-infection, cells were washed twice with PBS, fixed in acetone/EtOH (1:1) and processed for RNA extraction.

\section{Cell viability test}

Cells $\left(1 \times 10^{6}\right)$ were seeded in triplicate into culture plates $24 \mathrm{~h}$ prior to treatment. Bacterial infections were performed as described for the standard lysostaphin/gentamycin protection assay. Control experiments using antiCD95 ligation $(1 \mu \mathrm{g} / \mathrm{ml})$ or etoposide ( $100 \mu \mathrm{M}$ final concentration) were included for cytotoxicity measurements with trypan blue. At 24 hours post-internalization, cells were washed and the viability of monolayers determined using Trypan blue dye exclusion. Viability was evaluated and expressed as a percentage of the control condition plate. In some cases, we examined combined culture supernatants and monolayers to detect the presence of non-viable detached cells. No difference was noted from viability measurements of monolayers alone.

\section{Mock infection and cytochalasin $D$ experiments}

Fixation and RNA extractions were identical for every condition as described above. Cells were pretreated $30 \mathrm{~min}$ utes prior infection with $1 \mu \mathrm{g} / \mathrm{ml}$ cytochalasin D (Sigma) and also 60 minutes post-infection. Culture supernatants were collected and non-adherent bacterial cells were harvested, washed twice with PBS and fixed. Cell surfaceattached bacteria were detached from A549 monolayer by rapid trypsin incubation, harvested, washed, and fixed. For mock infection, bacterial suspensions were prepared in IM in the absence of A549 cells.

\section{RNA extraction and purification}

For all experiments, material (host cells or free bacteria) were lysed in the presence of ice cold acetone:ethanol (1:1) for 4 minutes. Cell monolayers were maintained on ice, then scraped and centrifuged briefly at $4^{\circ} \mathrm{C}$. Cellular debris and bacterial pellets were suspended in ice cold RLT buffer (Qiagen) and centrifuged, then washed four times

Table 2: List and characteristics of oligonucleotides used in the qPCR control experiments

\begin{tabular}{|c|c|c|c|c|}
\hline Primer or Probe name & Sequence $\left(5^{\prime} \rightarrow 3^{\prime}\right)$ & Length & A5'Dye & ORF number in N3 I 5 \\
\hline HU & & & & SAI305 \\
\hline F_HU_34 & CAAAGAGAAAACATGGTTACCATTATTAA & 29 & & \\
\hline R_HU_135 & CTCAAGCACCTCATAAGGATTATCAG & 26 & & \\
\hline P_HU_83A & AAAAGCCTATGGAAATTGCCCTCGCA & 26 & FAM & \\
\hline agrA & & & & SAI844 \\
\hline F_agrA_34 & CAAAGAGAAAACATGGTTACCATTATTAA & 29 & & \\
\hline R_agrA_I35 & CTCAAGCACCTCATAAGGATTATCAG & 26 & & \\
\hline P_agrA_83A & AAAAGCCTATGGAAATTGCCCTCGCA & 26 & FAM & \\
\hline sarS & & & & SA0I08 \\
\hline F_sarS_553 & САССАTAAATACССТСAAACTGTTAGAG & 28 & & \\
\hline R_sarS_638 & TCATCTTCAGTTGAGCGTTCTTTT & 24 & & \\
\hline P_sars_596B & AAAAGCAAGGCTATCTAA & 18 & FAM & \\
\hline lytM & & & & SA0265 \\
\hline F_lytM_32 & CGATGGGCTTCGCTACATTT & 20 & & \\
\hline R_lytM_105 & ATGTGCTTGTTGGGTGTTTGTC & 22 & & \\
\hline P_lytM_56 A & TGGCGCATCAAGCAGATGCAGC & 22 & FAM & \\
\hline sodA & & & & SAI382 \\
\hline F_sodA_l68 & TGTTGCTAATTTAGACAGTGTACCAGCTA & 29 & & \\
\hline R_sodA_275 & TCCCAGAATAATGAATGGTTTAAATG & 26 & & \\
\hline P_sodA_198A & CATCCAAACTGCTGTACGTAATAATGGCGG & 30 & FAM & \\
\hline sirA & & & & SAOIII \\
\hline F_sirA_I5I & GGGAAACCAAAGCGTGTTGT & 20 & & \\
\hline R_sirA_246 & TGTCCATGATTCTACAGCACCTACA & 25 & & \\
\hline P_sirA_198A & ATATCAAGGTGCCACTGACGTCGCTGT & 27 & FAM & \\
\hline
\end{tabular}

A Taqman probes with a 3'-TAMRA quencher (Eurogentec, Seraing, Belgium).

B Minor groove binder probe with non-fluorescent quencher bound to the 3'end (Applied Biosystems). All experiments used concentrations of 200 $\mathrm{nM}$ and $100 \mathrm{nM}$ for primers and probes, respectively. Primers and probe for hla quantification have been published previously $[87,88]$. 
in ice cold TE (10 mM Tris/HCl, $1 \mathrm{mM}$ EDTA $\mathrm{pH}$ 8.0). Fixed and washed bacteria were lysed in TE containing $200 \mu \mathrm{g} / \mathrm{ml}$ lysostaphin for 15 minutes at $37^{\circ} \mathrm{C}$ as previously described $[87,88]$. RNA was purified using RNeasy columns (Qiagen) following the manufacturer's instructions. For each infection experiment, RNA from 6 wells was pooled. Purified total RNA extracts were treated with MicrobENRICH (Ambion) following the manufacturer's instructions. RNA quality and yields were monitored before and after enrichment using a 2100 BioAnalyzer (Agilent) on PicoLab chip kit (Agilent).

\section{cDNA synthesis, amplification, and fluorescent labeling}

Total RNA (300 ng per condition) was converted into cDNA by Superscript II (Invitrogen) and amplified following a previously described method [89] yielding limited bias and robust amplification [90]. Briefly, $20 \mathrm{ng}$ of ds cDNA was amplified using the Genomiphi kit (Amersham Biosciences) according to the manufacturer's recommendations, then labeled with Cy3-dCTP (Perkin Elmer) using BioPrime DNA Labeling System (Invitrogen). Cy5dCTP (Perkin Elmer) labeled genomic DNA (0.5 mg) pooled from $S$. aureus strains N315, Mu50, COL, and MW2 was used as reference for the normalization process, according to previous work $[53,91]$.

\section{S. aureus microarray and hybridization conditions}

The S. aureus 60-mer oligonucleotide microarray contains 8455 oligonucleotides probes covering $>99 \%$ of genes of 4 sequenced $S$. aureus strains: N315, Mu50, MW2 and COL [53]. Labeled cDNA (signal channel, Cy3) and genomic DNA (control channel, Cy5) were mixed in 250 $\mu \mathrm{L}$ Agilent hybridization buffer and hybridized at $60^{\circ} \mathrm{C}$ for 17 hours. Slides were washed, dried under nitrogen, and scanned at $100 \%$ photomultiplier tube power for both wavelengths (Agilent). Microarrays for all experimental time-points were performed in triplicate.

\section{Data analysis}

Local background subtracted signals were calculated from three independent experiments using Feature Extraction software (Agilent version A6.1.1). To ensure spot quality, features and their respective background which were not uniform in pixel fluorescence intensity distribution in both channels were flagged (non-uniformity outlier flagging algorithm). Spots showing a genomic DNA reference signal not significantly different from corresponding background were also flagged (two-tailed Student's $t$-test feature versus background with $p<0.05$ ). Raw data were imported and analyzed using GeneSpring 7.2 (Agilent). Data were normalized using both per spot (signal channel divided by the corresponding control channel and generation of $\log _{10}$ ratio) and per chip (to the $50^{\text {th }}$ percentile). Flagged spots of low quality were excluded from further analysis. Replicates from the same test condition were grouped and the mean calculated. Significance of normalized data was determined using Welch's approximate $t$ test adjusting individual $P$ values with the BenjaminiHochberg correction for false discovery rate multiple test. Genes showing significant change in expression between two conditions and fold change $\geq 3$ were defined as differentially expressed. Fold changes for the complete dataset is available online as additional file 2 .

The analysis of differential gene expression patterns in nine possible combinations when comparing 0,2 , and 6 $\mathrm{h}$ was performed using the Welch conditional parametric test and false discovery rate correction (variances assumed unequal, $p<0.05$ ). Genes showing fold changes $>1.5$ are shown.

\section{Quantitative PCR}

To confirm microarray results, the expression levels of $h l a$, sigB, agrA, sodA, sarS and lytM genes were determined by real-time PCR analysis. Genomiphi-amplified material (1 ng) from independent experiments was assembled with specific primers (Invitrogen) and fluorescent probes (Table 2) designed using the PrimerExpress software (Applied Biosystems) in specific enzymatic kit mixtures (Eurogentec). PCR reactions were performed in a final volume of $20 \mu \mathrm{l}$ in a SDS7700 (Applied Biosystems). Relative expression levels were determined by comparing cycle threshold $(\mathrm{Ct})$ of each gene to the $\mathrm{Ct}$ value of the $h u$ gene for the same cDNA preparation [92].

\section{Authors' contributions}

CG contributed to the design of the study, performed the totality of microarray experiments including RNA extraction, amplification and data analysis, PF and JS conceived the study, contributed to experimental design and analysis and coordinated final writing, CT contributed to the real-time PCR validation experiments, $\mathrm{AH}$ and $\mathrm{YC}$ contributed to the design of the microarray and developed the required bioinformatics, SL was involved in microarray interpretation, SC was involved in the design and interpretation of results obtained in the infection model, AR was involved in microarray interpretation and contributed to MS elaboration, DL and PV contributed to manuscript elaboration, WK was involved in the design, experiments and analysis related to the infection model including apoptosis experiments and in the elaboration of the manuscript. 


\section{Additional material}

\section{Additional file 1}

Reproducibility of RNA amplification. cDNA was generated in 2 separate reactions from the same RNA pool, amplified independently and hybridized in 2 different arrays. Labeled cDNA from the starting material was used as control. Dye normalized intensities of amplified material are plotted in both axis.

Click here for file

[http://www.biomedcentral.com/content/supplementary/14712164-8-171-S1.tiff]

\section{Additional file 2}

Fold changes at $2 h$ and $6 h$ of all genes compared to control bacteria. Values represent mean of fold change from 3 or 4 independent biological replicates. ${ }^{*}$ Some genes are classified in two different COG categories and appear on separate lines in the table.

Click here for file

[http://www.biomedcentral.com/content/supplementary/14712164-8-171-S2.pdf]

\section{Additional file 3}

Genes differentially expressed grouped by function. Values represent mean of fold change from 3 or 4 independent biological replicates. ${ }^{*}$ Some genes are classified in two different COG categories and appear on separate lines in the table.

Click here for file

[http://www.biomedcentral.com/content/supplementary/1471-

2164-8-171-S3.pdf]

\section{Acknowledgements}

This work was supported by grants from the Swiss National Science Foundation PPOOB-I03002/I (JS), 3200B0-10840I (DL), 3100A0-I00425 (WK) and 3I00A0-I I6075 (PF). We are grateful to Christine Barras, Manuela Bento and Elzbieta Huggler for excellent technical assistance. CG performed the study as part of the post-graduate course in experimental medicine supported by the University of Zurich.

\section{References}

I. Fey PD, Said-Salim B, Rupp ME, Hinrichs SH, Boxrud DJ, Davis CC, Kreiswirth BN, Schlievert PM: Comparative molecular analysis of community- or hospital-acquired methicillin-resistant Staphylococcus aureus. Antimicrob Agents Chemother 2003, 47:196-203.

2. Lowy FD: Staphylococcus aureus infections. N Engl J Med 1998, 339:520-532.

3. Novick RP: Autoinduction and signal transduction in the regulation of staphylococcal virulence. Mol Microbiol 2003, 48: | 429-|449.

4. Archer GL: Staphylococcus aureus: a well-armed pathogen. Clin Infect Dis 1998, 26:1179-II8I.

5. Vojtov N, Ross HF, Novick RP: Global repression of exotoxin synthesis by staphylococcal superantigens. Proc Natl Acad Sci U S A 2002, 99:10102-10107.

6. De Boer ML, Kum WW, Pang LT, Chow AW: Co-production of staphylococcal enterotoxin A with toxic shock syndrome toxinI (TSST-I) enhances TSST-I mediated mortality in a Dgalactosamine sensitized mouse model of lethal shock. Microb Pathog 1999, 27:61-70.

7. De Boer ML, Kum WW, Chow AW: Staphylococcus aureus isogenic mutant, deficient in toxic shock syndrome toxin-I but not staphylococcal enterotoxin A production, exhibits attenuated virulence in a tampon-associated vaginal infection model of toxic shock syndrome. Can J Microbiol I999, 45:250-256.

8. Kernodle DS, Voladri RK, Menzies BE, Hager CC, Edwards KM: Expression of an antisense hla fragment in Staphylococcus aureus reduces alpha-toxin production in vitro and attenuates lethal activity in a murine model. Infect Immun 1997 , 65: $179-184$

9. Lew DP, Waldvogel FA: Osteomyelitis. Lancet 2004, 364:369-379.

10. Gittelman PD, Jacobs JB, Lebowitz AS, Tierno PM Jr.: Staphylococcus aureus nasal carriage in patients with rhinosinusitis. Laryngoscope 1991, 101:733-737.

II. Brook I, Finegold SM: Bacteriology of chronic otitis media. JAMA 1979, 241:487-488.

12. Kauffman CA, Terpenning MS, He X, Zarins LT, Ramsey MA, Jorgensen KA, Sottile WS, Bradley SF: Attempts to eradicate methicillin-resistant Staphylococcus aureus from a long-term-care facility with the use of mupirocin ointment. Am J Med 1993, 94:37|-378.

13. Powers KA, Terpenning MS, Voice RA, Kauffman CA: Prosthetic joint infections in the elderly. Am J Med 1990, 88:9N-I3N.

14. Krut O, Sommer H, Kronke M: Antibiotic-induced persistence of cytotoxic Staphylococcus aureus in non-phagocytic cells. J Antimicrob Chemother 2004, 53:167-173.

15. Lowy FD: Is Staphylococcus aureus an intracellular pathogen? Trends Microbiol 2000, 8:34I-343.

16. Alexander EH, Hudson MC: Factors influencing the internalization of Staphylococcus aureus and impacts on the course of infections in humans. Appl Microbiol Biotechnol 200I, 56:361-366.

17. Sinha B, Francois PP, Nusse O, Foti M, Hartford OM, Vaudaux P, Foster TJ, Lew DP, Herrmann M, Krause KH: Fibronectin-binding protein acts as Staphylococcus aureus invasin via fibronectin bridging to integrin a5b I. Cell Microbiol 1999, I:I01-II7.

18. Que YA, Haefliger JA, Piroth L, Francois P, Widmer E, Entenza JM, Sinha B, Herrmann M, Francioli P, Vaudaux P, Moreillon P: Fibrinogen and fibronectin binding cooperate for valve infection and invasion in Staphylococcus aureus experimental endocarditis. J Exp Med 2005, 201: I627-1635.

19. Clément S, Vaudaux P, Francois P, Schrenzel J, Huggler E, Kampf S, Chaponnier C, Lew D, Lacroix JS: Evidence of an Intracellular Reservoir in the Nasal Mucosa of Patients with Recurrent Staphylococcus aureus Rhinosinusitis. J Infect Dis 2005, 192:1023-1028.

20. Brouillette E, Grondin G, Lefebvre C, Talbot BG, Malouin F: Mouse mastitis model of infection for antimicrobial compound efficacy studies against intracellular and extracellular forms of Staphylococcus aureus. Vet Microbiol 2004, I 01:253-262.

21. Cossart P: Bacterial invasion: a new strategy to dominate cytoskeleton plasticity. Dev Cell 2004, 6:314-315.

22. Sinha B, Francois P, Que YA, Hussain M, Heilmann C, Moreillon P, Lew $D$, Krause $\mathrm{KH}$, Peters $\mathrm{G}$, Herrmann $\mathrm{M}$ : Heterologously expressed Staphylococcus aureus fibronectin-binding proteins are sufficient for invasion of host cells. Infect Immun 2000, 68:687I -6878.

23. Dziewanowska K, Carson AR, Patti JM, Deobald CF, Bayles KW, Bohach GA: Staphylococcal fibronectin binding protein interacts with heat shock protein 60 and integrins: role in internalization by epithelial cells. Infect Immun 2000, 68:632I-6328.

24. Fowler T, Johansson S, Wary KK, Hook M: Src kinase has a central role in in vitro cellular internalization of Staphylococcus aureus. Cell Microbiol 2003, 5:4I7-426.

25. Kahl BC, Goulian M, Van Wamel W, Herrmann M, Simon SM, Kaplan G, Peters G, Cheung AL: Staphylococcus aureus RN6390 replicates and induces apoptosis in a pulmonary epithelial cell line. Infect Immun 2000, 68:5385-5392.

26. Bayles KW, Wesson CA, Liou LE, Fox LK, Bohach GA, Trumble WR: Intracellular Staphylococcus aureus escapes the endosome and induces apoptosis in epithelial cells. Infect Immun 1998, 66:336-342.

27. Haslinger-Loffler B, Kahl BC, Grundmeier M, Strangfeld K, Wagner B, Fischer U, Cheung AL, Peters G, Schulze-Osthoff K, Sinha B: Multiple virulence factors are required for Staphylococcus aureusinduced apoptosis in endothelial cells. Cell Microbiol 2005, 7:1087-1097.

28. Wesson CA, Liou LE, Todd KM, Bohach GA, Trumble WR, Bayles $\mathrm{KW}$ : Staphylococcus aureusagr and sar global regulators influence internalization and induction of apoptosis. Infect Immun 1998, 66:5238-5243.

29. Menzies BE, Kourteva I: Internalization of Staphylococcus aureus by endothelial cells induces apoptosis. Infect Immun 1998, 66:5994-5998.

30. Bantel H, Sinha B, Domschke W, Peters G, Schulze-Osthoff K, Janicke RU: a-Toxin is a mediator of Staphylococcus aureus-induced cell death and activates caspases via the intrinsic death pathway independently of death receptor signaling. J Cell Biol 200I, I 55:637-648.

31. Mempel M, Schnopp C, Hojka M, Fesq H, Weidinger S, Schaller M, Korting HC, Ring J, Abeck D: Invasion of human keratinocytes by 
Staphylococcus aureus and intracellular bacterial persistence represent haemolysin-independent virulence mechanisms that are followed by features of necrotic and apoptotic keratinocyte cell death. Br J Dermatol 2002, I 46:943-95I.

32. Goerke C, Fluckiger U, Steinhuber A, Zimmerli W, Wolz C: Impact of the regulatory loci agr, sarA and sae of Staphylococcus aureus on the induction of alpha-toxin during device-related infection resolved by direct quantitative transcript analysis. Mol Microbiol 200I, 40: 1439-I447.

33. Cheung AL, Ying P: Regulation of alpha- and beta-hemolysins by the sar locus of Staphylococcus aureus. J Bacteriol 1994 I 76:580-585.

34. Fournier B, Klier A, Rapoport G: The two-component system ArIS-ArIR is a regulator of virulence gene expression in Staphylococcus aureus. Mol Microbiol 200I, 41:247-26I.

35. Garvis S, Mei JM, Ruiz-Albert J. Holden DW: Staphylococcus aureus svrA: a gene required for virulence and expression of the agr locus. Microbiology 2002, 148:3235-3243.

36. Proctor RA, van Langevelde P, Kristjansson M, Maslow JN, Arbeit RD: Persistent and relapsing infections associated with small-colony variants of Staphylococcus aureus. Clin Infect Dis 1995, 20:95-102.

37. von Eiff C, Bettin D, Proctor RA, Rolauffs B, Lindner N, Winkelmann W, Peters G: Recovery of small colony variants of Staphylococcus aureus following gentamicin bead placement for osteomyelitis. Clin Infect Dis 1997, 25:1250-I25I.

38. Proctor RA, Kahl B, von Eiff C, Vaudaux PE, Lew DP, Peters G: Staphylococcal small colony variants have novel mechanisms for antibiotic resistance. Clin Infect Dis 1998, 27 SuppI I:S68-S74.

39. Vaudaux P, Francois P, Bisognano C, Kelley WL, Lew DP, Schrenzel J, Proctor RA, McNamara PJ, Peters G, von Eiff C: Increased expression of clumping factor and fibronectin-binding proteins by hemB mutants of Staphylococcus aureus expressing small colony variant phenotypes. Infect Immun 2002, 70:5428-5437.

40. Kahl BC, Belling G, Becker P, Chatterjee I, Wardecki K, Hilgert K, Cheung AL, Peters G, Herrmann M: Thymidine-dependent Staphylococcus aureus small-colony variants are associated with extensive alterations in regulator and virulence gene expression profiles. Infect Immun 2005, 73:4II 9-4I26.

41. Donati L, Quadri P, Reiner M: Reactivation of osteomyelitis caused by Staphylococcus aureus after $\mathbf{5 0}$ years. J Am Geriatr Soc 1999, 47: 1035-1037.

42. Matussek A, Strindhall J, Stark L, Rohde M, Geffers R, Buer J, Kihlstrom $E$, Lindgren PE, Lofgren S: Infection of human endothelial cells with Staphylococcus aureus induces transcription of genes encoding an innate immunity response. Scand J Immunol 2005 , 61:536-544.

43. Voyich JM, Braughton KR, Sturdevant DE, Whitney AR, Said-Salim B, Porcella SF, Long RD, Dorward DW, Gardner DJ, Kreiswirth BN, Musser JM, DeLeo FR: Insights into mechanisms used by Staphylococcus aureus to avoid destruction by human neutrophils. Immunol 2005, 175:3907-3919.

44. Kuroda M, Ohta T, Uchiyama I, Baba T, Yuzawa H, Kobayashi I, Cui L, Oguchi A, Aoki K, Nagai Y, Lian J, Ito T, Kanamori M, Matsumaru H, Maruyama A, Murakami H, Hosoyama A, Mizutani-Ui Y, Takahashi NK Sawano T, Inoue R, Kaito C, Sekimizu K, Hirakawa H, Kuhara S, Goto S, Yabuzaki J, Kanehisa M, Yamashita A, Oshima K, Furuya K, Yoshino C, Shiba T, Hattori M, Ogasawara N, Hayashi H, Hiramatsu K: Whole genome sequencing of meticillin-resistant Staphylococcus aureus. Lancet 200I, 357:1225-1240.

45. Baba T, Takeuchi F, Kuroda M, Yuzawa H, Aoki K, Oguchi A, Nagai Y, Iwama N, Asano K, Naimi T, Kuroda H, Cui L, Yamamoto K, Hiramatsu K: Genome and virulence determinants of high virulence community-acquired MRSA. Lancet 2002, 359:1819-1827.

46. Holden MT, Feil E], Lindsay JA, Peacock S], Day NP, Enright MC, Foster TJ, Moore CE, Hurst L, Atkin R, Barron A, Bason N, Bentley SD, Chillingworth C, Chillingworth T, Churcher C, Clark L, Corton C, Cronin A, Doggett ], Dowd L, Feltwell T, Hance Z, Harris B, Hauser H, Holroyd S, Jagels K, James KD, Lennard N, Line A, Mayes R, Moule S, Mungall K, Ormond D, Quail MA, Rabbinowitsch E, Rutherford K, Sanders M, Sharp S, Simmonds M, Stevens K, Whitehead S, Barrell BG, Spratt BG, Parkhill ]: Complete genomes of two clinical Staphylococcus aureus strains: Evidence for the rapid evolution of virulence and drug resistance. Proc Natl Acad Sci U S A 2004, I0I:9786-979I.

47. Gill SR, Fouts DE, Archer GL, Mongodin EF, Deboy RT, Ravel J, Paulsen IT, Kolonay JF, Brinkac L, Beanan M, Dodson RJ, Daugherty SC, Madupu R, Angiuoli SV, Durkin AS, Haft DH, Vamathevan J, Khouri $\mathrm{H}_{\text {, }}$ Utterback T, Lee C, Dimitrov G, Jiang L, Qin H, Weidman J, Tran K, Kang K, Hance IR, Nelson KE, Fraser CM: Insights on evolution of virulence and resistance from the complete genome analysis of an early methicillin-resistant Staphylococcus aureus strain and a biofilm-producing methicillin-resistant Staphylococcus epidermidis strain. / Bacteriol 2005, 187:2426-2438.

48. Diep BA, Gill SR, Chang RF, Phan TH, Chen JH, Davidson MG, Lin F, Lin J, Carleton HA, Mongodin EF, Sensabaugh GF, Perdreau-Remington $\mathrm{F}$ : Complete genome sequence of USA300, an epidemic clone of community-acquired meticillin-resistant Staphylococcus aureus. Lancet 2006, 367:731-739.

49. Herron LL, Chakravarty R, Dwan C, Fitzgerald JR, Musser JM, Retzel $E$, Kapur V: Genome sequence survey identifies unique sequences and key virulence genes with unusual rates of amino Acid substitution in bovine Staphylococcus aureus. Infect Immun 2002, 70:3978-398I.

50. Said-Salim B, Mathema B, Kreiswirth BN: Community-acquired methicillin-resistant Staphylococcus aureus: an emerging pathogen. Infect Control Hosp Epidemiol 2003, 24:45I-455.

5I. Beenken KE, Dunman PM, McAleese F, Macapagal D, Murphy E, Projan SJ, Blevins JS, Smeltzer MS: Global gene expression in Staphylococcus aureus biofilms. J Bacteriol 2004, 1 86:4665-4684.

52. Bischoff M, Dunman P, Kormanec J, Macapagal D, Murphy E, Mounts W, Berger-Bachi B, Projan S: Microarray-based analysis of the Staphylococcus aureussB regulon. I Bacteriol 2004, 186:4085-4099.

53. Charbonnier Y, Gettler BM, Francois P, Bento M, Renzoni A, Vaudaux $P$, Schlegel W, Schrenzel J: A generic approach for the design of whole-genome oligoarrays, validated for genomotyping, deletion mapping and gene expression analysis on Staphylococcus aureus. BMC Genomics 2005, 6:95.

54. Dunman PM, Murphy E, Hanney S, Palacio D, Tucker-Kellogg G, Wu S, Brown EL, Zagurski RJ, Shlaes D, Projan SJ: Transcription ProfilingBased Identification of Staphylococcus aureus Genes Regulated by the agr and/or sarA Loci. I Bacteriol 200I, 183:734I-7353.

55. Fitzgerald JR, Sturdevant DE, Mackie SM, Gill SR, Musser JM: Evolutionary genomics of Staphylococcus aureus: insights into the origin of methicillin-resistant strains and the toxic shock syndrome epidemic. Proc Natl Acad Sci U S A 200I, 98:882I-8826.

56. Koessler $\mathrm{T}$, Francois $\mathrm{P}$, Charbonnier $Y$, Huyghe A, Bento M, Dharan S, Renzi G, Lew D, Harbarth S, Pittet D, Schrenzel J: Use of Oligoarrays for Characterization of Community-Onset MethicillinResistant Staphylococcus aureus. J Clin Microbiol 2006, 44: 1040-1048.

57. Nambu $Y$, Beer DG: Altered surface markers in lung cancer. Lack of cell-surface Fas/APO-I expression in pulmonary adenocarcinoma may allow escape from immune surveillance. Methods Mol Med 2003, 74:259-266.

58. Puskas LG, Zvara A, Hackler L Jr., Van Hummelen P: RNA amplification results in reproducible microarray data with slight ratio bias. Biotechniques 2002, 32:1330-4, 1336, 1338, 1340

59. Wilson CL, Pepper SD, Hey Y, Miller CJ: Amplification protocols introduce systematic but reproducible errors into gene expression studies. Biotechniques 2004, 36:498-506.

60. Genomic Research Laboratory 2007 [http://www.genomic.ch/ sup5.php].

61. NCBI: Phylogenetic classification of proteins encoded in complete genomes. NCBI 2006 [http://www.ncbi.nlm.nih.gov/COG/ index.html].

62. Chen L, Yang J, Yu J, Yao Z, Sun L, Shen Y, Jin Q: VFDB: a reference database for bacterial virulence factors. Nucleic Acids Res 2005 , 33:D325-D328.

63. Tegmark K, Karlsson A, Arvidson S: Identification and characterization of SarHI, a new global regulator of virulence gene expression in Staphylococcus aureus. Mol Microbiol 2000 , 37:398-409.

64. Ramakrishnan R, Dorris D, Lublinsky A, Nguyen A, Domanus M, Prokhorova A, Gieser L, Touma E, Lockner R, Tata M, Zhu X, Patterson M, Shippy R, Sendera TJ, Mazumder A: An assessment of Motorola CodeLink microarray performance for gene expression profiling applications. Nucleic Acids Res 2002, 30:e30.

65. Plouin-Gaudon I, Clément S, Huggler E, Chaponnier C, Francois P, Vaudaux P, Lew D, Schrenzel J, Lacroix JS: Intracellular sanctuary for Staphylococcus aureus in chronic rhinosinusitis. Rhinology 2006, 44:249-254.

66. Runyen-Janecky LJ, Payne SM: Identification of chromosomal Shigella flexneri genes induced by the eukaryotic intracellular environment. Infect Immun 2002, 70:4379-4388.

67. Orihuela CJ, Radin JN, Sublett JE, Gao G, Kaushal D, Tuomanen El: Microarray analysis of pneumococcal gene expression during invasive disease. Infect Immun 2004, 72:5582-5596.

68. Pracht D, Elm C, Gerber J, Bergmann S, Rohde M, Seiler M, Kim KS, Jenkinson HF, Nau R, Hammerschmidt S: PavA of Streptococcus pneumoniae modulates adherence, invasion, and meningeal inflammation. Infect Immun 2005, 73:2680-2689. 
69. Eriksson S, Lucchini S, Thompson A, Rhen M, Hinton JC: Unravelling the biology of macrophage infection by gene expression profiling of intracellular Salmonella enterica. Mol Microbiol 2003, 47:103-118.

70. Lucchini S, Liu H, jin $\mathrm{O}$, Hinton JC, Yu J: Transcriptional adaptation of Shigella flexneri during infection of macrophages and epithelial cells: insights into the strategies of a cytosolic bacteria pathogen. Infect Immun 2005, 73:88-102.

7I. Boyce JD, Wilkie I, Harper M, Paustian ML, Kapur V, Adler B Genomic scale analysis of Pasteurella multocida gene expression during growth within the natural chicken host. Infect Immun 2002, 70:687I-6879.

72. Ramadurai L, Lockwood KJ, Nadakavukaren MJ, Jayaswal RK: Characterization of a chromosomally encoded glycylglycine endopeptidase of Staphylococcus aureus. Microbiology 1999 I 45 ( Pt 4):80I-808.

73. Weinrick B, Dunman PM, McAleese F, Murphy E, Projan SJ, Fang Y, Novick RP: Effect of mild acid on gene expression in Staphylococcus aureus. J Bacteriol 2004, I 86:8407-8423.

74. Skaar EP, Humayun M, Bae T, DeBord KL, Schneewind O: Ironsource preference of Staphylococcus aureus infections. Science 2004, 305:1626-1628.

75. Frisk A, Schurr JR, Wang G, Bertucci DC, Marrero L, Hwang SH, Hassett DJ, Schurr M]: Transcriptome analysis of Pseudomonas aer uginosa after interaction with human airway epithelial cells. Infect Immun 2004, 72:5433-5438.

76. Sebulsky MT, Speziali CD, Shilton BH, Edgell DR, Heinrichs DE: FhuD I, a ferric hydroxamate-binding lipoprotein in Staphylococcus aureus: a case of gene duplication and lateral transfer. J Biol Chem 2004, 279:53152-53159.

77. Lithgow JK, Hayhurst E], Cohen G, Aharonowitz Y, Foster SJ: Role of a cysteine synthase in Staphylococcus aureus. J Bacteriol 2004, 186: $1579-1590$.

78. Frees D, Chastanet A, Qazi S, Sorensen K, Hill P, Msadek T, Ingmer H: Clp ATPases are required for stress tolerance, intracellular replication and biofilm formation in Staphylococcus aureus. Mol Microbiol 2004, 54: I445- I 462.

79. Cheung AL, Bayer AS, Zhang G, Gresham H, Xiong YQ: Regulation of virulence determinants in vitro and in vivo in Staphylococcus aureus. FEMS Immunol Med Microbiol 2004, 40:1-9.

80. Bronner S, Monteil H, Prevost G: Regulation of virulence determinants in Staphylococcus aureus: complexity and applications. FEMS Microbiol Rev 2004, 28: 183-200.

8I. Xiong YQ, Van Wamel W, Nast CC, Yeaman MR, Cheung AL, Bayer AS: Activation and transcriptional interaction between agr RNAII and RNAIII in Staphylococcus aureus in vitro and in an experimental endocarditis model. J Infect Dis 2002, I 86:668-677.

82. Moisan H, Brouillette E, Jacob CL, Langlois-Begin P, Michaud S, Malouin F: Transcription of Virulence Factors in Staphylococcus aureus Small-Colony Variants Isolated from Cystic Fibrosis Patients Is Influenced by SigB. J Bacteriol 2006, I 88:64-76.

83. von Eiff C, Proctor RA, Peters G: Staphylococcus aureus small colony variants: formation and clinical impact. Int J Clin Pract Suppl 2000:44-49.

84. von Eiff C, Heilmann C, Proctor RA, Woltz C, Peters G, Gotz F: A site-directed Staphylococcus aureus hemB mutant is a smallcolony variant which persists intracellularly. J Bacteriol 1997, 1 79:4706-47|2

85. Qazi SN, Counil E, Morrissey J, Rees CE, Cockayne A, Winzer K, Chan WC, Williams P, Hill PJ: agr expression precedes escape of internalized Staphylococcus aureus from the host endosome. Infect Immun 200I, 69:7074-7082.

86. Balwit JM, van Langevelde P, Vann JM, Proctor RA: Gentamicinresistant menadione and hemin auxotrophic Staphylococcus aureus persist within cultured endothelial cells. I Infect Dis 1994, 170:1033-1037.

87. Li D, Renzoni A, Estoppey T, Bisognano C, Francois P, Kelley WL, Lew DP, Schrenzel J, Vaudaux P: Induction of fibronectin adhesins in quinolone-resistant Staphylococcus aureus by subinhibitory levels of ciprofloxacin or by sigma B transcription factor activity is mediated by two separate pathways. Antimicrob Agents Chemother 2005, 49:916-924.

88. Renzoni A, Francois P, Li D, Kelley WL, Lew D, Vaudaux P, Schrenzel $\mathrm{J}$ : Modulation of Fibronectin Adhesins and Other Virulence Factors in a Teicoplanin-Resistant Derivative of MethicillinResistant Staphylococcus aureus. Antimicrob Agents Chemother 2004, 48:2958-2965.

89. Francois P, Garzoni C, Bento M, Schrenzel J: Comparison of Amplification Methods for Transcriptomic Analysis of Low Abundance Prokaryotic RNA sources. J Microbiol Methods 2006, In Press:.
90. Pinard R, de Winter A, Sarkis GJ, Gerstein MB, Tartaro KR, Plant RN Egholm M, Rothberg JM, Leamon JH: Assessment of whole genome amplification-induced bias through high-throughput, massively parallel whole genome sequencing. BMC Genomics 2006, 7:216.

91. Talaat AM, Howard ST, Hale W, Lyons R, Garner H, Johnston SA: Genomic DNA standards for gene expression profiling in Mycobacterium tuberculosis. Nucleic Acids Res 2002, 30:e 104.

92. Chien Y, Manna AC, Projan SJ, Cheung AL: SarA, a global regulator of virulence determinants in Staphylococcus aureus, binds to a conserved motif essential for sar-dependent gene regulation. J Biol Chem 1999, 274:37169-37I76.
Publish with Biomed Central and every scientist can read your work free of charge

"BioMed Central will be the most significant development for disseminating the results of biomedical research in our lifetime. "

Sir Paul Nurse, Cancer Research UK

Your research papers will be:

- available free of charge to the entire biomedical community

- peer reviewed and published immediately upon acceptance

- cited in PubMed and archived on PubMed Central

- yours - you keep the copyright
BioMedcentral 